\title{
Elite Perceptions and Nigeria's Foreign Policy Process
}

\author{
Nurudeen O. Mimiko, Kikelomo A. Mbada*
}

\begin{abstract}
The study examined the perception of Nigerian elites on the role of the Nigerian Ministry of Foreign Affairs (MFA) in foreign policy formulation and implementation. It investigated how the nature and structure of the Nigerian State shaped the nation's foreign policy bureaucracy as represented by the MFA. The study employed primary and secondary data. Primary data were collected through unstructured interview. Respondents were purposively selected from the academia as well as from among the senior officers of the MFA, the Nigerian Institute of International Affairs (NIIA) and the Institute for Peace and Conflict Studies (IPCS) totaling 25 altogether. The eligibility criteria included knowledge of and contribution to the subject matter, as well as expertise and active participation in Nigeria's foreign policy process. Secondary data were sourced from official documents, books, journals, newspapers, news magazines, and Internet-based materials. Data were analyzed using thematic content analysis. From the result, $75 \%$ of respondents perceived the MFA as simply a rubber-stamp for the desires and preferences of the President and their kitchen cabinet. $65 \%$ of respondents held the view that the Federal Cabinet, National Assembly, think-tanks, and research-based institutions that should be decision units alongside the MFA, appeared to be for the most part, sidelined in foreign policy making. About $60 \%$ of respondents submitted that the political, socio-economic, religious, linguistic and ethnical configuration of the Nigerian state and its characteristic differences, impinged on foreign policy decisions and pursuits. The study concluded that the role of Nigeria's Ministry of Foreign Affairs in many cases was undermined. It was seen to be more visible in foreign policy implementation than in decision-making; allowed only marginal roles in decision making or simply used as mere administrative machinery to implement the desires and preferences of the political head and their kitchen cabinet.
\end{abstract}

Key words: Foreign policy, elites, bureaucracy, decision-making, institutions, Nigeria

\footnotetext{
* Department of Political Science, Faculty of Social Sciences, Obafemi Awolowo University, Ile-Ife, Nigeria Address all correspondences to: Kikelomo A. Mbada Department of Political Science, Faculty of Social Sciences, Obafemi Awolowo University, Ile-Ife, Nigeria E-mail: enteekas@yahoo.com
} 


\section{Introduction}

Globally, institutions have become very important in the process of policy making and implementation. Kofele-Kale ${ }^{1}$ argues that "in all states, to a greater or lesser degree, foreign policy emerges out of an institutional process and in most cases, it is extremely rare for foreign policy | 42 decision-making to be the responsibility of a single individual or a small group". Even where an individual has a pre-eminence in foreign policy decision-making, few still have to work through institutions. There is no gainsaying the fact that strong and effective institutions are quite essential for the success of the policy process of any country. In concert, Akindele ${ }^{2}$ avers that the existence of institutions "not only dignifies the decision-making process and creates respectability for policy outcomes, but also legitimizes both the policy process and its outcomes".

In the field of foreign policy, one institution that is statutorily established to play a major role in mutually-reinforcing foreign policy decision-making and implementation processes in Nigeria, is the Ministry of Foreign Affairs (MFA), complemented by its external arms called Missions, Embassies or High Commissions. It should be noted that variations exist in the nomenclature of this institution from one country to another. What is currently known as the MFA in Nigeria began in 1957 as a Department in the Cabinet Office ${ }^{3}$. It was only formally established in 1960, and afterwards renamed a number of times. Between 1960 and 1963, it was known as the Ministry of External Affairs and Commonwealth Relations; between 1963 and 1991, as Ministry of External Affairs; and in 1999, assumed its current name, the Ministry of Foreign Affairs. In creating the Ministry, its responsibilities were defined as the implementation and pursuit of Nigeria's foreign policy objectives and the promotion of Nigeria's interests in different parts of the world ${ }^{4}$.

Although the implementation of Nigeria's external relations rests, in the main, with the MFA, this is not to discount the fact that other ministries and government departments whose functions impinge on external policies also play a role ${ }^{5}$. The fact therefore is that, whereas, the MFA has primary responsibility, it is not the only institution involved with foreign affairs. Inputs from the Ministries of Finance, Commerce and Industry, Economic Development and Defence, amongst others, are equally important as they have areas of interface with foreign affairs, and responsibilities affecting foreign policy formulation and implementation ${ }^{6}$. The important point is that in terms of machinery, like the embassies abroad, it is the MFA that stands well above other governmental agencies and departments. It remains primarily the coordinating and implementing body ${ }^{7}$. Its essential role being the consultation with the home ministries and extra-ministerial departments because the link between home and foreign affairs demands that such consultation should be continuous and cooperative to avoid any misunderstanding of each other's interests ${ }^{8}$. This underlines the importance of the role of the MFA in furthering or impeding foreign policy articulation and implementation process ${ }^{9}$.

Even though an administrative agency, the MFA is involved in the formulation of the country's foreign policy. Constitutionally, the responsibility for making Nigeria's external policy lies with both the legislature and the executive arms of government. Nevertheless, during the immediate post-independence years, especially in the First Republic (1960-1966), the legislature was excluded from the formulation of foreign policy; a responsibility that remained in the domain of the office of the Prime Minister and the Cabinet secretariat. Olajide Aluko spotted that for the first 10 months of independence, the Prime Minister, Alhaji Tafawa Balewa, remained the Foreign Affairs Minister and in conjunction with the Cabinet Office, maintained a close control on Nigeria's foreign policy ${ }^{10}$. To this end, the Cabinet Office used to prepare policy papers on foreign relations and that, more often than not, the Prime Minister preferred these to inputs from the Ministry. The Foreign Minister at that time went along almost submissively with every decision of Balewa on many foreign policies issues ${ }^{11}$.

In a general reflection on Nigeria's foreign policy trajectory, the question arises if the MFA, to which the responsibility for the conduct of Nigeria's diplomatic relations is given, is allowed to play any tangible role in that regard. This question is raised, in part, against the background of the observation by Akindele ${ }^{12}$ that the Ministry "... is not centrally involved in the making of policy decisions as it should and as one would expect it" and also because of the contemplation that the quality of foreign policy is bound to be affected if the engine room (MFA) is not adequately utilized. 
This study was therefore compelling in the light of the need to establish how the nation's foreign policy bureaucracy as represented by the MFA, is able to balance its role as the actual locus of foreign policy decisions and actions taking into account the nature and character of the Nigerian state. The study examined the perception of Nigerian foreign policy elites on the role of the Nigerian Ministry of Foreign Affairs (MFA) in foreign policy formulation and implementation.

\section{Theoretical Framework}

The major assumption that underpines the use of the decision-making approach in this study is that foreign policy decisions do not simply emerge in response to external stimuli; rather they are processed through an identifiable machinery within the state, which is headed by a leader ${ }^{13}$. The formulation and implementation of foreign policy is not domiciled in the office of a single leader as the rational model of the decision-making approach would suggest ${ }^{14}$. Usually, foreign policy decisions, according to the bureaucratic politics model, is that which results from the interplay among executive and legislative organizations, public and private interests, as well as personalities who all play political games to advance particular interests ${ }^{15}$.

The bureaucratic politics model which is a decision-making model of the behavioural paradigm, essentially reflects images of decision-making structures and processes in the advanced industrialized economies, or developed countries, especially the advanced capitalist states ${ }^{16}$. It only marginally defines the foreign policy process in developing countries. For example, in a presidential system of government as in Nigeria, the President/Head of State cannot be treated as one player among many. His/her ability to have his/her way cannot be taken casually. The President chooses key personnel who, in the last resort, are responsible to him/her. Even though it is true that he/she has to obtain information from and discuss policy alternatives with bureaucrats, their freedom of action and their power is largely determined by the president ${ }^{17}$. His/her interest, perception and behaviour have an important effect on foreign policy. The bureaucratic politics model also accounts for the gap between policy decisions and policy implementation. It shows the ability of the MFA to use a number of techniques to influence the nature and content of decisions in the course of their implementation which could involve evading or disregarding instructions, intentionally taking precise instructions; delaying action; obeying the letter but not the spirit of the instruction, taking actions in the absence of specific instructions ${ }^{18}$ (Asobie, 1990: 32).

Empirical studies show that beyond being just a response to external stimuli, Nigeria's foreign policy is shaped largely by domestic variables. Prominent among these variables as aptly noted by Asobie $^{19}$ are the personality, perception, wishes and influence of the Prime Minister or the President of the country; the collective influence of the foreign policy elite; the structure and orientation of the Ministry of Foreign/External Affairs; the structure and degree of professionalism of the Foreign Service, and the competence of Foreign Service personnel; the quality of expertise in the broad field of international relations commanded by the Ministry of Foreign Affairs; religious and ethnic configuration; the composition and orientation of the legislature; and the weakness of public opinion. Some others are recommendations of periodic, ad-hoc people's conferences on foreign policy; findings of foreign policy research institutes; decentralization of the responsibility for foreign policy decision-making and implementation among several Ministries, and the consequent bureaucratic/organizational politics; the nature of the political party system and the pattern of control of the legislature by the political parties; and the nature of inter-agency relationships and contacts among all the bureaucratic units involved in foreign policy formulation and implementation.

\section{Bureaucratic Politics and Foreign Policy Decision-making}

The personalities of individual leaders play a critical role in foreign policy decision-making particularly in African countries. This is a function of the overall weakness of institutions in the 
African political setting ${ }^{20}$. However, this does not discount the role of bureaucratic institutions. There is hardly any modern state in which bureaucrats play no part in either formulating or implementing foreign policy decisions ${ }^{21}$. The current political landscape of Nigeria reflects a democratizing country and given this situation, one will observe that bureaucrats inevitably play a role whether crucial or trivial is another issue. The views of Graham Allison and Morton Halperin that the Bureaucratic Politics model is only useful for explaining policy outcomes in only industrialized countries therefore | 44 remains defective ${ }^{22}$.

Although the rational policy model of Allison perceives there to be a unitary actor, as was virtually the case in Balewa era, the bureaucratic politics model, considers many actors to be players who focus not on a single strategic issue but on many diverse intra as well as international problems ${ }^{23}$. This study, however, recognizes that both models are useful for analyzing Nigeria's foreign policy tenures since independence. In examining the role of the bureaucracy in the making of Nigerian foreign policy, the bureaucratic politics model is useful in the light of the fact that foreign policy decision-making and implementation in Nigeria go beyond the theory of a strong-leader approach (where a political leader takes ultimate decisions that could in fact result in a zero-sum game for other stakeholders), to demonstrate that developing nations like Nigeria do have organizational structures that deal with foreign policies ${ }^{24}$. According to Fawole ${ }^{25}$, the National Assembly, and Ministries, Departments and Agencies (MDAs) whose schedules of duties and functions have foreign policy implications are involved in the foreign policy process. Some of these may ordinarily appear passive to casual observers of foreign policy process, but they in actual fact have specific operations either central or tangential to foreign policy making. Some of these institutions/bureaucracies include the Ministries of Finance, Defence, Commerce, Information, Internal Affairs, Agriculture, the Armed Forces and Police, the National Drug Law Enforcement Agency (NDLEA), the National Agency for Food, Drug Administration and Control (NAFDAC), the Nigerian National Petroleum Corporation (NNPC), The Nigerian Institute of International Affairs (NIIA), Nigerian Customs, Nigerian Immigration Service (NIS), Federal Aviation Authority of Nigeria (FAAN), the Nigerian Maritime Authority (NMA), Nigerian Olympic Committee (NOC), the Nigerian Football Association (NFA), e.tc.

The rational-actor model on the other hand, is useful in showing the reality of subtle overarching predominance of the majority of Nigerian political leaders even in so-called democratic dispensations. In a seeming corroboration of this perspective, Fawole ${ }^{26}$ referred to the strong individualistic or "personalist" bent as underlining the Obasanjo foreign policy approach. He reported that Obasanjo demonstrated such grip on foreign policy that his administration rarely deferred to the Foreign Service except for implementation of policies or for necessary damage control after government may have implemented bad decisions.

\section{Research Method}

This study employed both primary and secondary data. Primary data were collected through unstructured interview. Respondents for this study were drawn from the academia, senior officers of the Nigerian MFA, Abuja, the Nigerian Institute of International Affairs, Lagos and the Institute of Peace and Conflict Studies, Lagos. The inclusion criteria for sampling are knowledge of and contribution to the subject matter, expertise and active participation in Nigeria's foreign policy process. A total of 25 respondents were purposively selected: 12 from among the senior officers of the Ministry of Foreign Affairs, Abuja, five from the Nigerian Institute of International Affairs, Lagos, two from the Institute of Peace and Conflict Studies, Abuja, and three academics drawn from the Departments of International Relations, and Political Science, Obafemi Awolowo University, Ile-Ife, Nigeria. Secondary sources included official documents, books, journals, articles, newspapers, Internet-based materials and publications of the MFA and the Nigerian Institute of International Affairs. Data were analyzed descriptively using thematic content analysis. 


\section{The MFA and Tenures of Foreign Policy in Nigeria}

Since the country's independence in 1960, Nigeria's foreign policy has been officially different in terms of method of formulation, implementation, character traits and style of political leaders and composition and extent of involvement of various stakeholders, as well as the domestic and international situations and circumstances that they had to deal with. With respect to the 1960-1966 period, it is difficult for anyone to say that the Ministry of External Affairs (MEA) played a creative role in foreign policy formulation. Aluko ${ }^{27}$ observed that the MEA was no more than a mere administrative machinery for Prime Minister Abubakar Tafawa Balewa. Balewa retained sole control of foreign affairs from independence till July 1961 and again from December 1964 till the January 1966 military coup. Even after Mr. Jaja Wachukwu had been appointed External Affairs Minister, the Prime Minister continued to remain a super-Foreign Minister exercising full and constant control over foreign affairs in a manner that had no parallel in any parliamentary system ${ }^{28} 29$.

Under the Major General Aguiyi Ironsi administration (January 1966-July 1966), the Foreign Service was relied upon to initiate foreign policy and articulate government's attitudes and pronouncements before they were released ${ }^{30}$. Fawole, ${ }^{31}$ and Adesola ${ }^{32}$ averred that the Ministry of External Affairs enjoyed a measure of autonomy in running its affairs because the art of governance was new to the military that was without any political experience. In line with the above view above, Abdullahi ${ }^{33}$ observed that military regimes relied heavily on civil servants and accorded the MFA more space for initiative in foreign policy administration apparently because the art and science of international politics was a vague to them.

Under Gowon's regime (July 29, 1966 till July 29, 1975), the country did not appear to have a well-articulated foreign policy ${ }^{34}$. Even though the country's presence and impact in international politics during this regime was fully engaged, especially after the outbreak of the war, the regime however did not have the touch of drama that underlined Murtala's, but was certainly effective given its set objectives all of which bothered on enhancing Nigeria's global status and respectability. Of the foreign policy style of General Gowon, Joe Garba commented, who emerged as Foreign Minister in the post-Gowon government,

One of the things that bothered of General Gowon's style was personalization of Nigeria's diplomacy"... "the Ministry of External Affairs seemed to have been frequently bypassed ${ }^{35}$. Selected cases in point to substantiate Joe Garba's assertion includes how General Gowon spent lavishly to please Nigeria's neighbours; bestowed largess on countries even as far away as Grenada and Guyana often without regard for or recourse to consultation, unilateral recognition of MPLA in 1975 without much consultation as the Ministry was effectively sidelined ${ }^{36} 37$.

Under Shagari (1979-1983), Nigeria witnessed retrogression in foreign policy ${ }^{38}$. Professor Ishaya Audu who was the External Affairs Minister was not a member of the National Party of Nigeria (the ruling party), let alone its inner policy caucus. He was, therefore seriously handicapped in his conduct of foreign policy as it was difficult for the Ministry of External Affairs to become an authoritative point of inter-ministerial coordination for external relations in all dimensions ${ }^{39}$. In this period, the Foreign Service witnessed the invasion of the service by non-career ambassadors. People were recruited into the service on the basis of political constituencies and not on need, resulting in over-staffing of the MFA. This brought about over-expenditure on personnel which created enormous problems especially on posting and promotion ${ }^{40}$. This legacy continues to plague the Foreign Service till present.

General Muhammadu Buhari, (1983-1985) had an unyielding personality and was responsible for the contempt with which Nigeria was treated in the West Africa sub-region as well as the disdain Britain evidently had for the country in that period ${ }^{41}$. Undoubtedly, General Buhari drove his own personal idiosyncrasy (as a tough-minded and disciplined military officer) to the extremes, forgetting that diplomacy is a delicate game of esoteric rules and procedures by which other countries understand and accept a country's views and the projection of its interests ${ }^{42}$. It was therefore not surprising that Nigeria got a lot of bad publicity from around the world and particularly her neighbours for his actions. This ranged from seizure and detention of a British aircraft and its passengers and crew in a 
diplomatic tit-for-tat for the reason that the Buhari government was incensed by Britain's involvement in the attempted abduction of Alhaji Umaru Dikko from London, a Nigerian political exile accused of having threatened to attack the Buhari government, closure of Nigeria's land borders and refusal to reopen them in spite of repeated entreaties from concerned Nigerians and neighbouring states that were hardest hit by the policy, and expulsion of millions of West Africans in 1985 who were declared illegal aliens ${ }^{43}{ }^{44}$. These decisions were out of tune with the declared Concentric Circles framework | 46 enunciated by his Foreign Minister, Agboola Gambari, which underscored Nigeria's foreign policy as giving priority to relations with Nigeria's neighbours. The iron-will of General Buhari prevailed on virtually all issues and thus denied the country's foreign policy of the expertise and finesse that Professor Gambari (an acclaimed expert in International Relations) could have brought into it. The MFA was put aside in major decisions and was often left to do the necessary damage control after the government would have already taken and implemented bad decisions ${ }^{45}{ }^{46}$. Friday Okai ${ }^{47}$, Director, Ministry of Foreign Affairs, Abuja, in line with the above reported that in both military and civilian administrations, counterbalancing forces cease initiation in formulation of foreign policy and only depend on the Ministry for implementation.

General Ibrahim Babangida, military President from 1985 to 1993, appointed Professor Bolaji Akinyemi, who was reputed for his immense intellectual acumen and practical experience in International Relations, as External Affairs Minister. General Babangida allowed Professor Akinyemi the latitude to work because he apparently needed him to help boost the country's diminished prestige and to bring international credibility to the junta's foreign policy ${ }^{48}$. General Babangida, alongside the MFA, was involved in securing Namibia's independence; sustaining Angola in its war to consolidate her independence; paving the way for the realization of majority rule and final dismantling of apartheid in South Africa; quelling the crisis in the Liberian civil war; re-establishing diplomatic relations with Israel broken in 1973; attending to war-torn Liberia and the Sierra Leone crisis reinstating deposed President Ahmed T. Kabbah to power ${ }^{49}$. However, once General Babangida consolidated his grip on power, he promptly relieved Akinyemi of his post and took effective control of the direction of foreign policy by appointing people who were more amenable to his own vision into the post.

Ambassadors Amedu ${ }^{50}$, Obisakin ${ }^{51}$ and Okai ${ }^{52}$ in explaining why General Babangida allowed his first Foreign Minister such latitude for initiative, observed that the military by training and orientation deals less with politics or international relations. According to Okai, "foreign policy is not their strong point, it was just recently introduced in their curriculum hence conventionally the military had depended on the public service (MFA) for advice and guidance". Ambassador Omogiade ${ }^{53}$ added that although the military worked closely with the MEA, the personality of military political heads somehow predominantly impacted foreign policy decision-making and implementation. In contrast, Fawole averred that since powers to make decisions were unregulated and unchecked by any law or constitution, the military ran foreign policy as they chose ${ }^{54}$.

Under General Sani Abacha (1993-1998), foreign policy was crudely mishandled. Due to his extreme personalization of decision-making, Abacha rendered organizations and institutions (including the MFA) literally impotent and irrelevant ${ }^{55}$. His personal stubbornness prevailed in policies and he executed a reactive foreign policy. The regime was incapable of foreseeing the devastating effects of some of its decisions, such as the hanging and its timing of the "Ogoni nine" just before that year's Commonwealth summit. These diplomatic blunders happened because General Abacha underrated the importance of consultations with the MFA ${ }^{56}{ }^{57}$. Abacha's ignorance was further demonstrated in appointing an acrimonious and combative Tom Ikimi, to replace a veteran career diplomat, Alhaji Baba Gana Kingibe as Foreign Minister. Tom Ikimi is reported to have frequently shunned the advice of experienced Foreign Service officers of the MFA and functioned as a rubberstamp to General Abacha's wishes, evidently because he lacked capacity to provide useful policy advice.

General Abdulsalami Abubakar (June 1998-May 1999) was more amenable to advice even though he enjoyed similar authoritarian powers that military rule could confer. He appointed a career diplomat, Ignatius Olisemeka as Foreign Minister whom he allowed the latitude to apply knowledge 
and expertise to garner goodwill for Nigeria. By means of his competence, the international community started to warm up to Nigeria again ${ }^{58}$.

President Umaru Musa Yar'Adua (May 2007-May 2010) was largely a very reclusive and quiet President who also was not physically healthy during most of his time in office. This meant that the Presidency did not play a very strong role in foreign affairs. Ufot Inamete ${ }^{59}$ argued that

A non-adequately assertive leadership of the MFA also meant that the Ministry was not able to use the low key role of the Presidency to play strong roles in the foreign affairs. Also the low-key executive role logically meant low-key legislative role.

\section{The Role of the Nigerian Ministry of Foreign Affairs}

In Nigeria and undoubtedly elsewhere, every government in power usually allocates administrative responsibilities to its agencies for the conduct and management of its multi-various functions of governance. The role of the Nigerian Ministry of Foreign Affairs is explicit in the extant Constitution of the Federal Republic of Nigeria, under the Fundamental Objectives and Directive Principles of State Policy, Chapter 2, Subsection 19, 1999. This does not run precisely in consonance with the following perspectives of Nigerian foreign policy elites on the role of the MFA. According to Bola Akintenrinwa ${ }^{60}$,

The MFA is the first actor required to translate into action, foreign policy embarked upon or adopted by government. The government of the day makes policies on different matters but on the matter of foreign policy as distinct from agricultural development for which we have the Ministry of Agriculture, the Ministry was set up to take on this capital role. It is the MFA that translates into action, government's policy via its foreign and home service (HQ). The MFA looks at reports from the Foreign Service and then works on recommendations which are forwarded to Mr. President. The MFA as a bureaucracy is different from the Ministry as a policy making institution. The Ministry is not just simply implementing, it can take on initiative by doing a memo to the president. However, essentially it is for implementation.

In the words of Uche Ajulu-Okeke ${ }^{61}$, the MFA serves to project national image abroad, represent national interest in foreign land and to articulate the role and the activities of the country as a legal person in international fora. It addresses the interest of Nigerian citizens. So it does representational, consular duties, conference diplomatic duties, negotiation, conflict resolution duties. In her words, it is a Ministry with a multi-purpose role outside the country.

Sunday Omoigiade ${ }^{62}$ identified the MFA as that machinery that formulates and operates foreign policy in the country in which it is domiciled. He further explained that the role of the MFA is more relevant than ever for the reason that in the contemporary global system, virtually every issue is globalized - one would find domestic interest tied to international interest. He stressed the significant role of the MFA in his observation that most developed countries accord their Foreign Ministries a pride of place and that this possibly underscores why foreign ministers routinely are de facto vice presidents. Joseph Ochogwu ${ }^{63}$ identified the MFA as the main initiator and driver of foreign policy. Pius Osuyikanmi ${ }^{64}$ highlighted the MFA's primary responsibility as initiating, reviewing and implementing policies that have to do with Nigeria's relations across the globe. He explained that the MFA serves as custodian of information to develop policy alternative action and advise the political head in adopting the best policy option in the country's external relations. According to him, apart from generating inputs into foreign policies, the MFA develops mechanism for implementation, monitoring, evaluation, re-appraisal with a view to giving an informed feedback through the policy

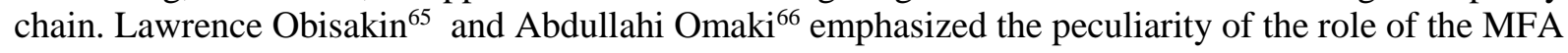
in terms of it being a clearing house for all other ministries in matters pertaining to foreign relations. In the view of Felix Aniokoye ${ }^{67}$, the MFA is the principal outlet for ventilating government decisions on foreign matters. 
A look at the opinions of the respondents reveals a general consensus that the MFA is indeed an implementing body. However, opinions are varied on whether it is a policy formulating body or its extent of involvement in foreign policy decision-making. Akindele ${ }^{68}$ however argues that an analysis of the role of the MFA as the intended, formal and central machinery for the conduct of Nigeria's foreign policy must be anchored to the conception of its dual role of policy making and policy implementation more as an interrelated and interpenetrative gamut of activities.

\section{The Nature and Structure of the Nigerian State}

Nigeria is a "social formation that is defined by its failures" as explicated in Mimiko ${ }^{69}$. Following a critical interrogation of the fundamental nature and structural character of the Nigerian State, several scholars have described the State as alienatory, irresponsible, weak, non-performing, captured, exploitative, cruel, dependent, illegitimate, oppressive and repressive, a limited democracy, violent, privatized, insensitive, unstable, vulnerable and useless for the generation of public good 707172737475 . Among several other challenges, the Nigerian State continues to grapple with the task of how to legitimize governance structure in the country by enhancing its delivery capacity ${ }^{76}{ }^{77}$. Of concern to this paper, is the broad consensus that the nature, character and politics of the Nigerian state as presently constituted, serves to pursue the parochial interests of the ruling elite. Following Mimiko ${ }^{78}$, these increasingly rapacious and insensitive (ruling) elite only show perfunctory commitment in the pursuit of the public good. As a result of this misuse, the Nigerian State reflects exhaustion and possibilities for failure.

Generally in a presidential system, there are different political bases of foreign policy conduct. According to Omaki Abdullahi ${ }^{79}$ the executive and the legislature are the two major political arms of government with constitutional roles in the conduct of foreign policy and inherent in these arms is the presence of bureaucrats in the coordination of the various inputs into the foreign policy process. In same view, Sunday Omogiade ${ }^{80}$ highlighted the role of the MFA as the coordinating bureaucratic agent for the cumulative inputs in the foreign policy process where foreign policy making structure, must take cognizance of the fact that in a presidential system of government, a popularly elected president is the chief executive, as is in Nigeria. According to him, the conduct of foreign policy as of any other public policy, must, in the final analysis, be examined in the wider context of the larger institutional interaction between the executive and the legislature and the other bureaucracies. He explained that how the interest of Nigeria is best served, is central in bureaucratic politics and that in arriving at this objective, there are several stakeholders: the president, civil society, press, political parties, private sector, academics, non-governmental organizations, the National Assembly, that must be taken into account.

On the foreign policy structure of the Nigerian state, Pius Osuyikanmi ${ }^{81}$ commented the president is the chief policy actor, whatever he says becomes a foreign policy statement. The formulation of the MFA is subject to approval by the executive council or the president. At the level of the executive, the ministries are divided into different areas of competencies. One of the areas where the Federal Government has under the exclusive list is the conduct of Nigeria's relations with other states be it bilateral or multilateral is the MFA. In the process of policy formulation in a presidential system of government, the ultimate decision maker is the political head. Political alternatives remain proposals until adopted by the Executive Council of the Federation or Head of State. Policy issues and specific decisions on specific matters are always a fall-out from a broad framework of policies. In other words, the Nigerian government, in responding to a specific issue may take a specific decision guided by a broad policy framework.

Bola Akintenrinwa ${ }^{82}$ explained that for the reason that the character of the Nigerian state is federal, the constitution only allows the federal government to enter into international relations, but not a constitutive state. According to him, when you look at the character of the federal government, it is only the MFA acting on behalf of the Federal Republic of Nigeria that can go international. That structure is not negotiable. Unlike under the First Republic where there were regions who could negotiate agreements with sovereign states under a parliamentary system. 
Akindele ${ }^{83}$, asserted that in a general reflection of Nigeria's foreign policy, there is abundant evidence to support the fact that the MFA, to which responsibility for the conduct of Nigeria's diplomatic relations with other countries has been assigned, has not been centrally involved in the making of policy decisions as it should and as one would expect because of the tradition of situating foreign policy leadership and activism in the office of the Prime Minister, Head of State or President. Corroborating, Idang ${ }^{84}$ refers to the situation from October 1960 to January 1966, where the MFA hardly played any creative role in foreign policy formulation because the Prime Minister at that time (Alhaji Sir Abubakar Tafawa Balewa) retained and exercised sole and constant control of foreign affairs notwithstanding the appointment of an external affairs Minister.

Akindele ${ }^{85}$ decried the frequent by-pass of foreign ministers, and condemned the personalization of Nigeria's diplomacy which according to him, would seem to be generally true of all Nigerian Heads of State. He submitted with regard to the locus of foreign policy making in Nigeria, that the MFA headed by the Foreign Minister, is not where the real action is, but that the Head of State coat-tailed by the Foreign Minister is the centre of gravity. In concert, Kolawole ${ }^{86}$ argued that it was improper that external affairs ministers were more often than not relegated to play a second fiddle to the president. He recommended that the process of foreign policy formulation be democratized to benefit from inputs of members of the domestic environment. In his words, 'Nigeria's foreign policy must move from the purview of the whims and caprices of ruling elite to the domain of enlarged and enlightened public'.

Okpokpo ${ }^{87}$ proposed that on important sensitive internal policy issues that would have effect on the country's foreign policy, a decision-making forum comprising Presidential Advisers, top-level officials from the Ministries of Foreign Affairs, Defence, Internal Affairs, Justice, Economy and Finance, the Nigerian Institute of International Affairs, the National Institute for Policy and Strategic Studies and the National Institute for Advanced Legal Studies, should meet to discuss with a view of defining coherent policy. Ajulu-Okeke ${ }^{88}$, recounts a Nigeria where the role of the MFA is not always appreciated unlike in developed countries of the globe. She attributes this anomaly to the systemic ailment affecting the entire Nigerian public service. She explains that while talking about the theoretical, the MFA should act as a sieve that collates information from the external environment, processes it in the MFA and sends it out to the various home ministries in the domestic environment for implementation and action. But the reality is that that is not the case in today's Nigeria because of the indiscipline at all levels of the polity and the poor regard for rules, due process and the rule of law. She added, you find out that every home ministry and every local government wants to become the MFA, wanting to establish their own links with foreigners, attend conferences without informing the MFA about what they do but run to the MFA when there are problems. State governors travel out without informing the MFA and they have by these acts of indiscipline, so encouraged unauthorized access to Nigeria because they deal directly with foreigners rather than through the MFA. Foreigners come into the country and deal directly with officials who are their clients without any recourse to the MFA. So the role of the MFA has been seriously buffeted by the indiscipline and systemic malaise in the national psyche.

She advocated that politicians should hands-off and must stop meddling in the affairs of the MFA. That by allowing the MFA to effectively function, the country invariably would be giving professionalism its due place. She lamented the situation of inaccessibility of the citizens to the prevailing elitist government, who the citizens conceive as an agent of privilege and not service delivery. She recommends that the 'bread and butter' needs of the majority of Nigerian citizens be attended to and provided so that the challenge of indiscipline of the populace could be addressed.

According to a respondent ${ }^{89}$ Under democratic dispensation, we have multipolar action and when this is added to national indiscipline, it results in mere chaos. Indiscipline accounts for multiple players in foreign policy administration in Nigeria. The National Assembly making foreign policy pronouncements without the intervention or knowledge of the executive, members of the Foreign Relations Committee likewise wanting to go do oversight duties abroad, etc. The nose-diving economic fortunes of the country, prompts persons to seek for perceived baskets of comforts in foreign travels and estacodes. As a result government representatives are made up very large delegations, majority of who go shopping when on such trips. 
One can deduce from the above contributions that the character of the Nigerian state necessarily determines foreign policy decisions and permits the MFA to exist and perform the way it has been doing. For instance the considerations that went into the issue of membership of Nigeria in the Organization of Islamic Countries (OIC) and breaking diplomatic ties with Israel, were largely informed by factors such as quota system, religious and linguistic sentiments. However, there is a consensus among respondents that the presidential system, run in a true democracy and federal system of government would enhance the role of the MFA.

Onifade $^{90}$ and Sabella ${ }^{91}$ have argued that the lack of dynamism in and pale achievements of Nigeria's foreign policy are not unrelated to the MFA's failure to be proactive. Hence the call for suitable Ministers of Foreign Affairs who would operate with clear vision and represent the visibility and substance of past External Affairs Ministers like Jaja Wachukwu, Arikpo Okoi, Joseph Garba and Bolaji Akinyemi in Nigeria's external relations. They propose relative freedom for Ministers by heads of government, arguing that ministers aforementioned were successful at their task because they were allowed considerable latitude to operate by their political heads. Gambari ${ }^{22}$, a past Minister of External Affairs, opined that the Ministry of External Affairs would better meet the challenge of operating as the primary instrument for making and implementing foreign policy, by working for a better motivated, increasingly better trained, and better managed Ministry capable of producing well-thought out, clearly articulated, and generally well-implemented foreign policy".

\section{Summary of findings}

The thematic content analysis of the role of the MFA in the conduct of foreign policy is presented in Table 1. As regards the perception of elites on the role of the MFA, the result showed that $75 \%$ of the respondents perceived that foreign ministers and by extension the MFA, were less involved in foreign policy decision-making than in the implementation. $80 \%$ were of the opinion that a very small political group (composed and coordinated by the President/Head of State) takes decisions and formulates foreign policies, $75 \%$ agreed that the MFA is used to rubber-stamp the desires and preferences of an executive and his kitchen cabinet. 58\% of respondents agreed that the structure, orientation and competence of the staff of the MFA, determined the role of the MFA. 85\% believed that the role of the MFA is defined by the leadership personality or idiosyncrasy of the political head. $65 \%$ of respondents held the view that the Federal Cabinet, National Assembly, think-tanks, and research-based institutions that should be decision units alongside the MFA, appeared to be for the most part, sidelined in foreign policy making. Pertaining to determining factors in foreign policy decisionmaking, $60 \%$ of respondents were of the opinion that socio-demographic factors such as religion and ethnicity, influenced foreign policy formulation. The nature of the presidential system of government as a determinant of the role of the MFA, was supported by $50 \%$ of the respondents. This study corroborates findings of previous studies that show that the current role of the MFA in foreign policy conduct is a departure from that stipulated in the 1999 Nigerian Constitution (Table 1).

\section{Conclusion}

The MFA characteristically plays second fiddle in terms of policy formulation even though it has to implement decisions emanating from the office of the president. It happens this way especially when the political head takes particular interest in foreign policy issues unlike in cases where the president defers to the foreign affairs minister for several other reasons. The point that cannot be overstated is that, given the dynamic nature of foreign policy making and implementation, consultations with the MFA is a sine qua non for coherent and effective foreign policy and as a result the MFA more than ever before, should be allowed substantive space in both foreign policy formulation and implementation. 
The summary of the thematic content analysis shows that the MFA, that should be a fundamental decision unit in the conduct of foreign policy, has time and again, been sidelined in policymaking. It was perceived to be more visible in foreign policy implementation than in decisionmaking; allowed only marginal roles in decision making or simply used as mere administrative machinery to implement the desires and preferences of an executive and his kitchen cabinet.

Table 1: Thematic content analysis of the perception of elites on the role of the MFA and other determining factor of foreign policy conduct in Nigeria $(\mathrm{N}=25)$

Theme

$\#(\%)$

\section{Perception on the role of the MFA}

1. Foreign ministers and by extension the MFA, was less involved in foreign policy decision-making than perhaps in the implementation

2. The MFA translates into action government's policy via its foreign and home service

3. The MFA is used to rubber-stamp what are the desires and preferences of an executive and his kitchen cabinet

4. The role of the MFA is determined by the leadership personality or idiosyncrasy of the president $85(25)$

5. The MFA is the machinery that formulates foreign policy and represents the Nigeria's interest

6. A very small political group (composed and coordinated by the President/Head of State) takes decisions and formulates policies

7. The contributions of professional diplomats and research-based institutions always cumulatively and fundamentally represent an indispensable ingredient in Nigeria's foreign policy formulation

\section{Determining factors in foreign policy formulation and implementation}

1. Presidential system of government

2. The structure and orientation of the Ministry of Foreign Affairs and the degree of professionalism or competence of the Foreign Service personnel

3. The nature of the political party system and the pattern of control of the legislature by the political parties

4. The composition and orientation of the legislature

5. The collective influence of the foreign policy elite

6. Public opinion

7. Religion and ethnicity

8. The nature of inter-agency relationships and contacts among all the bureaucratic units involved in foreign policy conduct

NB: $\mathrm{N}$ represents total number of respondents 


\section{End notes}

${ }^{1}$ Kofele-Kale, N (1981). 'Cameroon and its Foreign Relations', African Affairs, 1981, Vol. 80, pp. 197-217.

2 Akindele, R.A. (2005), 'An Institutional Approach to Nigeria's Foreign Policy Formulation and Implementation: A Study of the Role of the MFA' in Ogwu, U.J. (eds), New Horizons for Nigeria in World Affairs, (Lagos: The Nigerian Institute of International Affairs), pp. 51-53.

${ }^{3}$ Ashiru,O. A. (2011), Seminar to Review Nigeria's Foreign Policy, 28 ${ }^{\text {th }}$ July, 2011

${ }^{4}$ Ofoegbu, R. (1999), 'The Structure and Process of Foreign Policy Formulation and Implementation: A Study of the Ministry of External Affairs', in Olusanya, G.O. and Akindele, R.A., (eds), The Structure and Processes of Foreign Policy Making and Implementation in Nigeria, 1960-1990 (Ibadan: Vantage Publishers International Ltd.), pp.72-105.

${ }^{5}$ Ogunbadejo, O. 'Nigeria's External Relations: The Role of the Foreign Office', unpublished paper $1 \& 2$.

${ }^{6}$ Fawole W.A. (2004), Understanding Nigeria's Foreign Policy under Civilian Rule since 1999, (Ibadan, College Press Publishers Ltd).

${ }^{7}$ Afinotan, L.A. (2007), 'Technocrats and Nigerian Foreign Policy: Analysis of the Roles of Bolaji Akinyemi and Ibrahim Gambari in Nigeria's Foreign Policy', a PhD thesis, of University of Ado-Ekiti.

${ }^{8}$ Chibundu, V.N. (2009), Foreign Policy: With Particular Reference to Nigeria (1961-1008), Ibadan: Spectrum Books Ltd. p29.

${ }^{9}$ Inamete, U.B. (2001), Foreign Policy Decision Making in Nigeria, India: Susquehanna University Press. Pp 31, 176

${ }^{10}$ Aluko, O. (1981), Essays on Nigeria Foreign Policy, (London: George Allen and Unwin). p 162

${ }^{11}$ Idang, G.J. (1973), Nigeria's Internal Politics and Foreign Policy, 1960-1966, (Ibadan: Ibadan University Press) p6.

12 Akindele, R.A. (1990), 'The Operation and Management of Nigeria's Foreign Policy System: Reflections on the Experience of the First Thirty Years', in Olusanya, G.O. and Akindele, R.A. (eds), The Structure and Processes of Foreign Policy Making and Implementation in Nigeria, 1960-1990 (Ibadan: Vantage Publishers International Ltd.), P.532.

13 White B. 'Analysing Foreign Policy: Problems and Approaches' in Clarke M., White B. (1992), Understanding Foreign Policy: The Foreign Policy Systems Approach. Aldershot : Edward Elgar, pp.1-26.

${ }^{14}$ Stein, J.G. 'Foreign Policy Decision-Making: Rational, Psychological, and Neurological Models'. Accessed via http://www.oup.com/uk/orc/bin in 6th September 2013.

${ }^{15}$ Hudson, V.M. (2007), Foreign Policy Analysis: Classic and Contemporary Theory, (Plymouth: Rowman \& Littlefield Publishers Inc.) p65.

${ }^{16}$ Asobie, H. (1980), "The Foreign Policy of a Developing Nation: An Analysis", in EC Amucheazi, (ed.), Readings in Social Sciences; Issues in National Development, (Enugu: Fourth Dimension Publishers), pp. 59-79.

${ }^{17}$ Clarke, M. \& White, B. (1989), Understanding Foreign Policy: The Foreign Policy Systems Approach, (Aldershot: Edward Elgar Publishing) p15.

${ }_{18}$ Asobie, H. (1990), 'Decision-Making Models Re-visited: An Analysis of the Application of Theories and Models of Foreign Policy Decision-Making to the Study of Nigeria's Foreign Policy', in G. O. Olusanya and R. A. Akindele, (eds.) The Structure and Processes of Foreign Policy Making and Implementation in Nigeria, 1960-1990', (Ibadan: Vantage Publishers International, p32)

${ }_{19}$ Asobie, H. (1980), "The Foreign Policy of a Developing Nation: An Analysis", in EC Amucheazi, (ed.), Readings in Social Sciences; Issues in National Development, (Enugu: Fourth Dimension Publishers), pp. 59-79.

${ }^{20}$ Zartman, I.W. (1966), International Relations in the New Africa, in Mimiko, N.O. (2010), Swimming Against the Tide: Development Challenges for the Long-Disadvantaged in a Fundamentally Skewed Global System, Inaugural Lecture Series 233, Obafemi Awolowo University, Ile- Ife, Nigeria.

${ }^{21}$ Shaw, T. and Aluko O. (1983) Nigerian Foreign Policy: Alternative Perceptions and Projections (London: Macmillan and New York: St. Martin's) p77.

${ }^{22}$ Ibid, 77-79

${ }^{23}$ Ibid, 78

${ }^{24}$ Smith, B. L. (2003). 'Public Policy and Public Participation Engaging Citizens and Community in the Development of Public Policy', Health Canada.

${ }^{25}$ Fawole W.A. (2004), Understanding Nigeria's Foreign Policy under Civilian Rule since 1999, (Ibadan, College Press Publishers Ltd) p8.

${ }^{26}$ Fawole, W. A. (2000) 'Obasanjo's Foreign Policy: Nigeria's Return to Global Reckoning?', Nigerian Journal of International Affairs, Vol. 26, No. 2.

${ }_{27}$ Aluko, O. (1981), Essays on Nigeria Foreign Policy, (London: George Allen and Unwin) p24.

${ }^{28}$ Idang, G.J. (1973), Nigeria: Internal Politics and Foreign Politics, 1960-1966, Ibadan: Ibadan University Press, 113. 
${ }^{29}$ Inamete, U.B. (1981) 'Foreign Policy Decision Making in Nigeria', India: Susquehanna University Press p 41.

${ }^{30}$ Inamete, U.B. (1981) 'Foreign Policy Decision Making in Nigeria', India: Susquehanna University Press p43.

${ }^{31}$ Interview conducted with Professor Fawole, W.A., Department of International Relations, Obafemi Awolowo University, Ile-Ife.

${ }^{32}$ Interview conducted with Dr. Adesola, F., Department of International Relations, Obafemi Awolowo

University, Ile-Ife.

${ }^{33}$ Interview conducted with Ambassador Ogbole Amedu, Spokesperson, Ministry of Foreign Affairs, Abuja.

${ }^{34}$ Anifowose, R. and Enemuo, F, (1999), Elements of Politics, Lagos: Sam Iroanusi Publications p73.

${ }^{35}$ Garba, J. (1987), Diplomatic Soldering: Nigerian Foreign Policy, 1975-1979, Ibadan: Spectrum Books p4.

${ }^{36}$ Fawole, W. A. (2003), Nigeria's External Relations and Foreign Policy under Military Rule (1966-1999), (Ile-Ife: Obafemi Awolowo University Press Limited) pp 13-14.

${ }^{37}$ Garba, J. (1987), 'Diplomatic Soldering: Nigerian Foreign Policy, 1975-1979', Ibadan: Spectrum Books p 32.

38 Akinboye S.O. 'Nigeria's Foreign Policy', in Anifowose, R. and Enemuo, F. (1999), Elements of Politics, Lagos: Sam Iroanusi Publications p380.

${ }^{39}$ Gambari, I.A. 'Diplomatic Practice and Foreign Policy Theory: My Experience as Foreign Minister and Permanent Representative of Nigeria', in Akintenrinwa, B.A. (2004), 'Nigeria's New Foreign Policy Thrust: Essays in Honour of Ambassador Oluyemi Adeniji, CON, Ibadan: Vantage Publishers p26.

${ }^{40}$ Anifowose, R. and Enemuo, F, (1999), Elements of Politics, Lagos: Sam Iroanusi Publications pp 376-378.

41 Ezirim, G.E (2011), 'Fifty Years of Nigeria's Foreign Policy: A Critical Review', Sacha International Academic Journal, www. academia.edu/345652 p6.

${ }^{42}$ Akintenrinwa, B.A. (2004), Nigeria's New Foreign Policy Thrust: Essays in Honour of Ambassador Oluyemi Adeniji, CON, Ibadan: Vantage Publishers p23.

${ }^{43}$ Ibid, 13, 14, 147

${ }^{44}$ Fawole, W. A. (2003), Nigeria's External Relations and Foreign Policy under Military Rule (1966-1999), (Ile-Ife: Obafemi Awolowo University Press Limited) pp3,14, 138, 143.

${ }^{45}$ Gambari, I.A. (1989), Theory and Reality in Foreign Policy Making: Nigeria after the Second Republic, Atlantic Highlands, NJ: Humanities Press International Inc. pp.51-59.

${ }^{46}$ Fawole, W. A. (2003), Nigeria's External Relations and Foreign Policy under Military Rule (1966-1999), (Ile-Ife: Obafemi Awolowo University Press Limited) p138.

${ }^{47}$ Interview conducted with Mr. Friday Okai, Officer, Ministry of Foreign Affairs, Abuja.

${ }^{48}$ Ibid, 24, 154.

${ }^{49}$ Anifowose, R. and Enemuo, F, (1999), Elements of Politics, Lagos: Sam Iroanusi Publications p378.

${ }^{50}$ Interview conducted with Amedu op cit

${ }^{51}$ Interview Ambassador Lawrence Obisakin, Director, Ministry of Foreign Affairs, Abuja.

${ }^{52}$ Interview conducted with Okai op cit

${ }^{53}$ Interview conducted with Ambassador Sunday Omoigiade, Director, Planning, Ministry of Foreign Affairs.

${ }^{54}$ Fawole, W. A. (2003), Nigeria's External Relations and Foreign Policy under Military Rule (1966-1999), (Ile-Ife: Obafemi Awolowo University Press Limited).

${ }^{55}$ Ibid, 14, 15, 189.

${ }^{56}$ Akinboye, J. O. (2005). Executive Behaviour Battery. Ibadan: Stirling-Horden Publishers p 217.

${ }^{57}$ Anifowose, R. and Enemuo, F, (1999), Elements of Politics, Lagos: Sam Iroanusi Publications p381.

${ }^{58}$ Fawole, W. A. (2003), Nigeria's External Relations and Foreign Policy under Military Rule (1966-1999), (Ile-Ife: Obafemi Awolowo University Press Limited) p17, 33-34.

${ }^{59}$ Interview conducted with Prof. Ufot Inamete, Professor of Political Science, A. and M. University,

Tallahassee, Florida, USA.

${ }^{60}$ Interview conducted with Prof. Bola Akinterinwa, Director, The Nigerian Institute of Foreign Affairs, Lagos.

${ }^{61}$ Interview conducted with Ambassador Mrs. Uche Ajulu-Okeke, Director, Research \& Statistics, Ministry of Foreign Affairs, Abuja.

62 Interview conducted with Ambassador Sunday Omoigiade, op cit

${ }^{63}$ Interview conducted with Mr. Joseph Ochogwu, Principal Research Officer/Technical Advisor, Institute of Peace and Conflict studies, Abuja.

${ }^{64}$ Interview conducted with Dr. Pius Osuyinkanmi, Special Adviser to the President on International Relations, State House, Presidential Villa, Abuja.

${ }^{65}$ Interview conducted with Ambassador Lawrence Obisakin, op cit.

${ }^{66}$ Interview conducted with Ambassador Abdullahi Omaki, Director, Ministry of Foreign Affairs, Abuja.

${ }^{67}$ Ambassador Felix Ani-okoye (Rtd), Ministry of Foreign Affairs, Abuja. 
${ }^{68}$ Akindele (2005) 'An Institutional Approach to Nigeria's Foreign Policy Formulation and Implementation: A Study of the Role of the MFA' in Ogwu, U.J., New Horizons for Nigeria in World Affairs, (Lagos: Nigeria Institute of International Affairs, pp. 52-53.

${ }^{69}$ Mimiko, N.O. (2010), Swimming Against the Tide: Development Challenges for the Long-Disadvantaged in a Fundamentally Skewed Global System, Inaugural Lecture Series 233, Obafemi Awolowo University, Ile- Ife,

70 Ake, C. (1981). A Political Economy of Africa, London: Longman.

${ }^{71}$ Mimiko, N.O. (2010), Swimming Against the Tide: Development Challenges for the Long-Disadvantaged in a Fundamentally Skewed Global System, Inaugural Lecture Series 233, Obafemi Awolowo University, Ile- Ife, Nigeria.

${ }^{72}$ Ihonvbere, J. (2008), The Nigerian State as Obstacle to Federalism, http://julius.ihonvbere.com/2008/09.

${ }^{73}$ Okowa, W. (2005) 'Oil, Babylonian Mathewnomics and Nigerian Development', University of Port Harcourt, Inaugural Lecture Series No. 40.

74 Orugbani, A. (2002) 'Class Interest and State Policy in Africa: The Nigerian Experience' in Efemini (ed) Ake and African Development, Selected Issues: Nigeria Paragraphic.

${ }^{75}$ Okaba, B. (2003). 'The State, Oil Multinationals and Informal Repression in the Niger Delta', AFAS Journal of Minority Studies, Vol. 3, No. 1.

${ }^{76}$ Mimiko, N.O. (2007), 'Political and Constitutional Reform in Reform', in Anifowose, R. and Babawale, T. (eds), Nigeria Beyond 2007: Issues, Challenges and Prospects, Lagos: Concept Publications.

${ }^{77}$ Abbass, (2010), 'The Nigerian State and the Responsibility of Historians' being a Paper Prepared for the First Festschrift Conference Organized by Bayero University, Kano, in honour of Professor Dahiru Yahya, October, 2010 at BUK Kano.

${ }^{78}$ Mimiko N.O. (2006), 'Census in Nigeria: The Politics and the Imperative of De-politicization', African Asian Studies, 5(1), Netherlands, pp1-21.

${ }^{79}$ Ambassador Omaki Abdullahi, op cit

${ }^{80}$ Ambassador Sunday Omoigiade, op cit

${ }^{81}$ Dr. Pius Osuyinkanmi, op cit

${ }^{82}$ Prof. Bola Akintenrinwa, op cit

${ }^{83}$ Akindele (2005) 'An Institutional Approach to Nigeria's Foreign Policy Formulation and Implementation: A Study of the Role of the MFA' in Ogwu, U.J., New Horizons for Nigeria in World Affairs, (Lagos: Nigeria Institute of International Affairs p 58.

${ }^{84}$ Idang, G.J. (1973), Nigeria: Internal Politics and Foreign Politics, 1960-1966, Ibadan: Ibadan University Press,:113.

${ }^{85}$ Akindele (2005) 'An Institutional Approach to Nigeria's Foreign Policy Formulation and Implementation: A Study of the Role of the MFA' in Ogwu, U.J., New Horizons for Nigeria in World Affairs, (Lagos: Nigeria Institute of International Affairs p57.

${ }^{86}$ Kolawole D. (2005), 'From Isolation to Globalization: Transformation of Nigeria's Foreign Policy from the Abacha Regime to the Obasanjo Administration', in Pakistan Journal of Social Sciences Vol.3, Grace Publication.

${ }^{87}$ Okpokpo, E. (1999), 'The Challenge Facing Nigeria's Foreign Policy in the Next Millennium', 3(2):4. [online] URL: http://web.africa.ufl.edu/asq/v3/v313al6.htm

${ }^{88}$ Interview conducted with Ambassador Ajulu-Okeke, op cit

${ }^{89}$ Interview conducted with anonymous respondent

90 Onifade, A. (2003) 'Scorecard of Nigeria's Foreign Relations in 2003', http://nigeriaworld.com/feature/publication/123003.html, accessed 30 ${ }^{\text {th }}$ December, 2012.

${ }_{91}$ Sabella O. A. 'Foreign Policy and Nigeria's External Affairs Ministers', The Punch, Lagos, Thursday, $5^{\text {th }}$ August, 2010.

92 Gambari, I.A. (1989), Theory and Reality in Foreign Policy Making: Nigeria After the Second Republic, Atlantic Highlands, NJ: Humanities Press International Inc. p26. 